\title{
The Role of Work-Family Psychological Contract in the Relationships between Affectivity and Job Satisfaction
}

\author{
Mardhiah Mat Jusoh ${ }^{1}$, Aminah Ahmad ${ }^{2}$ \& Zoharah Omar ${ }^{1}$ \\ ${ }^{1}$ Department of Professional Development and Continuing Education, Faculty of Educational Studies, Universiti \\ Putra Malaysia, Serdang, Malaysia \\ ${ }^{2}$ Institute for Social Science Studies, Universiti Putra Malaysia, Serdang, Malaysia \\ Correspondence: Aminah Ahmad, Institute for Social Science Studies, Universiti Putra Malaysia, 43400 UPM \\ Serdang, Selangor, Malaysia. Tel: 60-3-89471871. E-mail: aminahahmad49@gmail.com
}

Received: August 29, 2013 Accepted: November 22, 2013 Online Published: December 29, 2013

doi:10.5539/ass.v10n2p183 URL: http://dx.doi.org/10.5539/ass.v10n2p183

\begin{abstract}
In recent years, studies have shown that with the increase in the number of dual-career couples and greater job demand from employers, employees have to deal with work-family role imbalance. Hence, many employees have demanded assistance for non-work or family activities. The absence of a strong legal contract on work-family benefits to help employees deal with work-family role imbalance has resulted in employees relying on psychological agreements or contracts. This paper presents a model that includes personality factors (positive affectivity and negative affectivity) as independent variables, work-family psychological contract as a mediator and job satisfaction as the dependent variable. This model was developed based on the 'conservation of resources theory' as well as previous research findings. This model extends the content of psychological contract to include work-family issues by introducing the work-family psychological contract concept and postulates the role of work-family psychological contract as a mediator in the relationships between affectivity and job satisfaction.
\end{abstract}

Keywords: work-family psychological contract, affectivity, job satisfaction

\section{Introduction}

The increase of woman workers has created another new scenario in the workforce whereby the number of dual-earner couples has also increased (Aminah, 2011). This means that more couples are juggling both work and family roles (Perrewe', Treadway, \& Hall, 2003) and are experiencing difficulty in balancing these roles (Baral \& Bhargava, 2010). The experience of work-family role imbalance affects employees' job satisfaction (Saltzstein, Ting, \& Saltzstein, 2001). Research has shown that employees who received family-friendly programs at the workplace had high levels of job satisfaction (Saltzstein, Ting, \& Saltzstein, 2001). It is also found that low levels of job satisfaction may reduce the morale of employees who then tend to work less and concentrate less on their jobs and inadvertently this is a loss to the organization due to the decrease in productivity and efficiency (Varawalla, 2009).

This situation has forced organizations to take action to help employees manage their work and family role demands and increase their job satisfaction (Baral \& Bhargava, 2010). The importance of workplace family support in generating positive organizational outcomes has been reported (Lapierre et al., 2008; Aminah \& Zoharah, 2013). Many organizations in developed countries have formulated work-family policies to help employees deal with this situation by integrating employees' work and family roles (Jones \& McKenna, 2002). In Malaysia, although the government sector has been more generous in providing work-family benefits as compared to the private sector, the work-family policy is still at its early stage of development (Aminah, 2007). The absence of a strong regard for legal contracts in terms of work-family policies suggests that such an exchange relationship may depend on psychological, social, and interpersonal mechanisms rather than formalisms arising from legal provisions. Employees and employers may come into a psychological contract or agreement about employer assistance in non-work activities.

According to Rousseau (1995), psychological contracts are "individuals' beliefs, shaped by the organization, regarding terms of an exchange agreement between individuals and their organizations" (p. 9). Although there 
have been many studies on psychological contract, only a few have used the psychological contract concept to deal with work-family issues (Conway \& Briner, 2002). Moreover, many studies on psychological contracts only focus on testing theories and discussing them in general (DelCampo, 2007). In this paper, work-family psychological contract refers to unwritten beliefs held by employees regarding what has been promised to employees by organizations regarding the integration of work and family roles. In other words, work-family psychological contract reflects an employee's expectations regarding an organization's obligations and these expectations are based on what has been promised by the organization regarding work-family benefits.

According to Conway and Briner (2005), a psychological contract can be shaped by individual factors such as the individual's personality. This paper suggests that psychological contract potentially provides a useful mechanism through which the relationships between personality factors and job satisfaction can be examined. Psychological contract plays a key role in shedding light on contemporary employment relationships (Sels, Janssens, \& Van den Brande, 2004; Sturges et al., 2005; Pate, 2006). This paper extends the content of psychological contract to include work-family issues by introducing the work-family psychological contract concept and investigate the role of this contract as a mediator in the relationships between personality factors and job satisfaction.

Drawing from the classical 'conservation of resources theory' (Hobfoll, 1989), this model presents the mediating effect of work-family psychological contract on the relationships between positive affectivity, negative affectivity and job satisfaction (Figure 1).

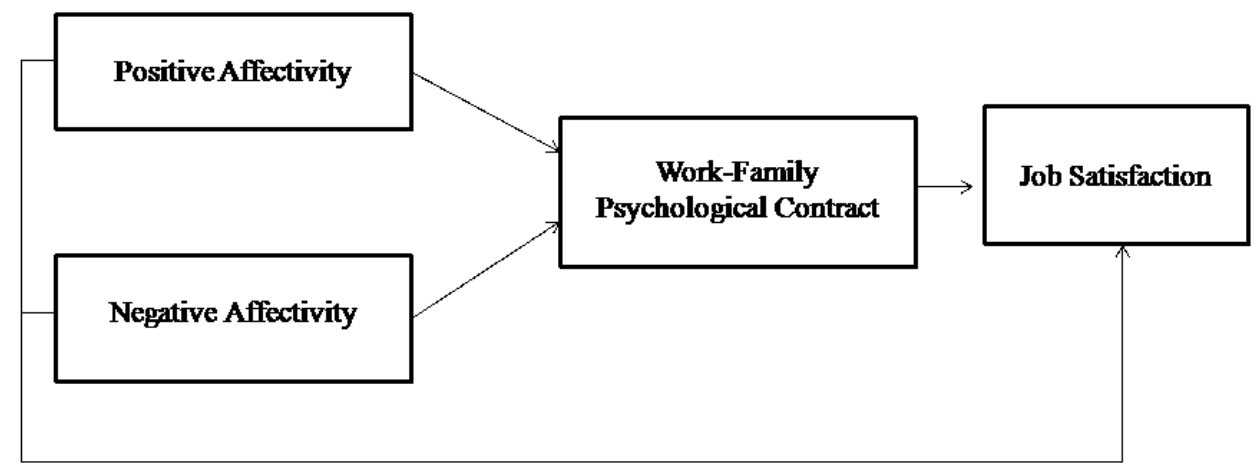

Figure 1. Model on the mediating effect of work-family psychological contract on the relationships between positive affectivity, negative affectivity and job satisfaction

\section{Literature Review}

\subsection{Conservation of Resources Theory}

The present model is grounded on the 'conservation of resources theory' (Hobfoll, 1989), which suggests that individuals will strive to protect their resources from any loss. Resources here refer to objects, conditions, personal characteristics, or energy, which are valued by individuals (Hobfoll, Freedy, Lane, \& Geller, 1990).

In this model, personality factors (positive affectivity and negative affectivity) are recognized as 'personal characteristic resources' that individuals may protect from any loss so that other resources, namely work-family psychological contract and job satisfaction may in turn be protected. Work-family psychological contract is identified as a 'condition resource' that is protected to ensure that individuals are satisfied with their jobs.

In line with this theoretical perspective, it seems reasonable to view work-family psychological contract as a resource for employees who believe that the organization is fulfilling its obligations to help them balance work and family roles, and hence increase satisfaction in their jobs.

\subsection{Positive Affectivity, Negative Affectivity and Job Satisfaction}

Affectivity is a characteristic that describes how individuals experience emotions and react to their environment (Brouer \& Harris, 2007). Individuals with positive affectivity are typically enthusiastic, confident, energetic and active while individuals with high negative affectivity are characterized as distressed, disagreeable and tense (Heller, Judge, \& Watson, 2002). An individual with high negative affectivity is described as nervous, anxious, and tense, while an individual with low negative affectivity is seen as calm and quiet (Brouer \& Harris, 2007). High negative affectivity individuals tend to dwell on their failures and shortcomings and see themselves as unhappily engaged (Bouckenooghe, Raja, \& Butt, 2013). Individuals with high positive affectivity are illustrated 
as joyful and confident (Toegel, Anand, \& Kilduff, 2007). These individuals have a generalized sense of well-being and are predisposed to experience positive emotional states as well as a tendency to espouse positive views of oneself and the world (Bouckenooghe, Raja, \& Butt, 2013). Both positive affectivity and negative affectivity have also been linked to the major personality traits of extraversion and neuroticism from the Big Five model of personality traits (Bouckenooghe, Raja, \& Butt, 2013). Relying on meta-analytic data, Ilies and Judge (2003) found that positive and negative affectivity could better explained genetic sources of job satisfaction than the Big Five traits.

According to Bouckenooghe, Raja, and Butt (2013) positive and negative affectivities influence key work outcomes such as job satisfaction, job performance and intention to quit. It is critical to understand how positive affectivity and negative affectivity relate to key attitudes such as job satisfaction because employees' organizational lives are imbued with affect (Bouckenooghe, Raja, \& Butt, 2013). Positive affectivity and negative affectivity are positive and negative sources of energy (Watson, 2000) that may motivate people to perform well or discourage them from doing so. Whether one will mobilize these negative or positive sources of energy will depend on the evaluation or assessment of his or her own job (Bouckenooghe, Raja, \& Butt, 2013). Individuals who habitually experience positive emotions (high positive affectivity) report higher job satisfaction, and individuals who habitually experience negative emotions (high negative affectivity) report lower job satisfaction (Templer, 2012). Connolly and Viswesvaran (2000) reported that both positive affectivity and negative affectivity were moderately correlated with job satisfaction. Research by Bruk-Lee, Khoury, Nixon, Goh, and Spector (2009) found that positive affectivity was positively related to job satisfaction, and negative affectivity was negatively related to job satisfaction. According to Lent et al., (2011) individuals with high positive affectivity may have high levels of satisfaction with their jobs. This is because individuals with positive affectivity always look at the bright side of their job, and hence they feel satisfied with their jobs (Grafton, Ang, \& Macleod, 2012). Diefendorff, Erickson, Grandey, and Dahling (2011) illustrated that individuals with negative affectivity may feel dissatisfied with their jobs because they are easily depressed. Moreover, in the case of negative affectivity, the experience of negative emotions such as distress and anxiety will deplete the resources required for satisfaction on job (Bouckenooghe, Raja, \& Butt, 2013).

\subsection{Positive Affectivity, Negative Affectivity and Work-Family Psychological Contract}

The study of relationships between affectivities (positive affectivity and negative affectivity) and psychological contract has not been given much attention compared to other personality studies (Grafton, Ang, \& Macleod, 2012). According to Turnley and Feldman (1999), individuals with negative affectivity were inclined to have negative perceptions on psychological contracts. They tend to develop negative perceptions toward their organizations in terms of reciprocating obligations at the workplace. This happens because individuals with negative affectivity are likely to pay attention on what they do not gain or gain less from the psychological contract than what they have received. Thus, employees may not have positive beliefs about their organizations pertaining to assistance in integrating work and family roles. On the other hand, individuals with positive affectivity are known to be more calm and optimistic (Brouer \& Harris, 2007). Turnley and Feldman (1999) found that individuals with positive affectivity might have positive perceptions on psychological contracts. Hence, they are more likely to believe that their organizations will help them integrate work and family roles.

Research by Guerrero and Herrbach (2008) found that perceptions on psychological contracts are influenced by positive affectivity and negative affectivity. Individuals who experience positive affectivity may generate mindsets that their organizations would fulfill psychological contracts. In other words, individuals with positive affectivity tend to perceive that their organizations would reciprocate their obligations regarding work-family issues. Conversely, individuals with negative affectivity are linked to distress and anxiety, and the experience of negative events on the job is likely to be related over time to negative perceptions of psychological contract fulfillment.

\subsection{Work-Family Psychological Contract and Job Satisfaction}

Psychological contract is a key management concern as it can have an impact on employees' attitudes including job satisfaction (Beynon, Heffernan, \& McDermott, 2012). Research on psychological contract and job satisfaction shows that these two factors are positively related (McDonald \& Makin, 2000; Allen, 2001; Gordon, Whelan-Berry, \& Hamilton, 2007; Chambel \& Alcover, 2011). A study by Baral and Bhargava (2010) shows that psychological contract is positively correlated to job satisfaction. Beynon, Heffernan, and McDermott (2012) suggested that breach of psychological contract might have negative effects on employees' attitudes such as job satisfaction. Chao, Cheung, and $\mathrm{Wu}$ (2011) found that breaching the psychological contract would lower employees' job satisfaction. It can be expected that fulfillment of the psychological contract may enhance 
employees' job satisfaction because when employees belief that their organizations have fulfilled obligations in helping their employees integrate work and family responsibilities, employees would feel satisfied with their jobs. Conway, Guest, and Trenberth (2011) also found that fulfillment of psychological contract may increase employees' satisfaction toward their jobs. Thus, it seems reasonable to view that work-family psychological contract would positively contribute to job satisfaction.

\section{Conclusion}

The absence of a strong legal contract on work-family benefits to help employees deal with work-family role imbalance has resulted in employees relying on psychological agreements or contracts. In the past, studies on psychological contract have only focused on traditional contents such as emoluments, promotions and training. Due to the significance of work-family issues, the model developed in this paper has introduced a new content of the psychological contract namely, work-family integration.

The model includes personality factors (positive affectivity and negative affectivity) as independent variables, work-family psychological contract as a mediator and job satisfaction as the dependent variable. The model developed in this paper is based on the conservation of resources theory, and work-family and psychological contract literature. This model would help provide a greater understanding of the mechanism by which the work-family psychological contract, positive affectivity, and negative affectivity are linked to job satisfaction of employees.

\section{References}

Allen, T. D. (2001). Family-supportive work environments: The role of organizational perceptions. Journal of Vocational Behavior, 58(3), 414-435. http://dx.doi.org/10.1006/jvbe.2000.1774

Aminah, A. (2007). Family-friendly employment policy practices in the Malaysian government and selected private organizations. The Journal of Global Business Management, 3(1), 128-135.

Aminah, A. (2011). Coping behavior of junior physicians in managing conflict between work and family roles. Journal of American Science, 7(6), 513-517.

Aminah, A., \& Zoharah, O. (2013). Informal workplace family support and turnover intention: Testing a mediation model. Social Behavior and Personality, 41(4), 555-556. http://dx.doi.org/10.2224/sbp.2013.41.4.555

Baral, R., \& Bhargava, S. (2010). Work-family enrichment as a mediator between organizational interventions for work-life balance and job outcomes. Journal of Managerial Psychology, 23(5), 274-300. http://dx.doi.org/10.1108/02683941011023749

Beynon, M. J., Heffernan, M., \& McDermott, A. M. (2012). Psychological contracts and job satisfaction: Clustering analysis using evidential c-means and comparison with other techniques. Intelligent Systems in Accounting, Finance and Management, 19(4), 247-273. http://dx.doi.org/10.1002/isaf.1334

Bouckenooghe, D., Raja, U., \& Butt, A. N. (2013). Combined effects of positive and negative affectivity and job satisfaction on job performance and turnover intentions. The Journal of Psychology, 147(2), 105-123. http://dx.doi.org/10.1080/00223980.2012.678411

Brouer, R., \& Harris, K. (2007). Dispositional and situational moderators of the relationship between leader-member exchange and work tension. Journal of Applied Social Psychology, 37(7), 1418-1441. http://dx.doi.org/10.1111/j.1559-1816.2007.00219.x

Bruk-Lee, V., Khoury, H. A., Nixon, A. E., Goh, A., \& Spector, P. E. (2009). Replicating and extending past personality/job satisfaction meta-analyses. Human Performance, 22(2), 156-189. http://dx.doi.org/10.1080/08959280902743709

Chambel, M. J., \& Alcover, C. M. (2011). The psychological contract of call-centre workers: Employment conditions, satisfaction and civic virtue behaviours. Economic and Industrial Democracy, 32(1), 115-134. http://dx.doi.org/10.1177/0143831X10376421

Chao, J. M. C., Cheung, F. Y. L., \& Wu, A. M. S. (2011). Psychological contract breach and counterproductive workplace behaviors: Testing moderating effect of attribution style and power distance. The International Journal of Human Resource Management, 2(4), 763-777. http://dx.doi.org/10.1080/09585192.2011.555122

Connolly, J. J., \& Viswesvaran, C. (2000). The role of affectivity in job satisfaction: A meta-analysis. Personality and Individual Differences, 29(2), 265-281. http://dx.doi.org/10.1016/S0191-8869(99)00192-0

Conway, N., \& Briner, R. B. (2002). A daily diary study of affective responses to psychological contract breach 
and exceeded promises. Journal of Organizational Behavior, 23, 287-302. http://dx.doi.org/10.1002/job.139

Conway, N., \& Briner, R. B. (2005). Understanding psychological contracts at work: A critical evaluation of theory and research. New York, NY, U.S.: Oxford University Press. http://dx.doi.org/10.1093/acprof:oso/9780199280643.001.0001

Conway, N., Guest, D., \& Trenberth, L. (2011). Testing the differential effects of changes in psychological contract breach and fulfillment. Journal of Vocational Behavior, 79, 267-276. http://dx.doi.org/10.1016/j.jvb.2011.01.003

DelCampo, R. G. (2007). Understanding the psychological contract: A direction for the future. Management Research News, 30(6), 432-440. http://dx.doi.org/10.1108/01409170710751926

Diefendorff, J. M., Erickson, R. J., Grandey, A. A., \& Dahling, J. J. (2011). Emotional display rules as work unit norms: A multilevel analysis of emotional labor among nurses. Journal of Occupational Health Psychology, 16(2), 170-186. http://dx.doi.org/10.1037/a0021725

Gordon, J. R., Whelan-Berry, K., \& Hamilton, E. A. (2007). The relationship among work-family conflict and enhancement, organizational work-family culture, and work outcomes for older working women. Journal of Occupational Health Psychology, 12(4), 350-364. http://dx.doi.org/10.1037/1076-8998.12.4.350

Grafton, B., Ang, C., \& Macleod, C. (2012). Always look on the bright side of life: The attentional basis of positive affectivity. European Journal of Personality, 26, 133-144. http://dx.doi.org/10.1002/per.1842

Guerrero, S., \& Herrbach, O. (2008). The affective underpinnings of psychological contract fulfilment. Journal of Managerial Psychology, 23(1), 4-17. http://dx.doi.org/10.1108/02683940810849639

Heller, D., Judge, T. A., \& Watson, D. (2002). The confounding role of personality and trait affectivity in the relationship between job and life satisfaction. Journal of Organizational Behavior, 23, 815-835. http://dx.doi.org/10.1002/job.168

Hobfoll, S. E. (1989). Conservation of resources: A new attempt at conceptualizing stress. American Psychologist, 44(3), 513-524. http://dx.doi.org/10.1037/0003-066X.44.3.513

Hobfoll, S. E., Freedy, J., Lane, C., \& Geller, P. (1990). Conservation of social resources: Social support resource theory. Journal of Social and Personal Relationship, 7, 465-478. http://dx.doi.org/10.1177/0265407590074004

Ilies, R., \& Judge, T. A. (2003). On the heritability of job satisfaction: The mediating role of personality. Journal of Applied Psychology, 88(4), 750-759. http://dx.doi.org/10.1037/0021-9010.88.4.750

Jones, W. M., \& McKenna, J. (2002). Women and work-home conflict: A dual paradigm approach. Health Education, 102(5), 249-259. http://dx.doi.org/10.1108/09654280210444128

Lapierre, L. M., Spector, P. E., Allen, T. D., Poelmans, S., Cooper, C. L., O’Driscoll, M. P., ... Kinnunen, U. (2008). Family-supportive organization perceptions, multiple dimensions of work-family conflict, and employee satisfaction: A test of model across five samples. Journal of Vocational Behavior, 73, 92-106. http://dx.doi.org/10.1016/j.jvb.2008.02.001

Lent, R. W., Nota, L., Soresi, S., Ginevra, M. C., Duffy, R. D., \& Brown, S. D. (2011). Predicting the job and life satisfaction of Italian teachers: Test of a social cognitive model. Journal of Vocational Behavior, 79, 91-97. http://dx.doi.org/10.1016/j.jvb.2010.12.006

McDonald, D. J., \& Makin, P. J. (2000). The psychological contract, organisational commitment and job satisfaction of temporary staff. Leadership \& Organization Development, 21(2), 84-91. http://dx.doi.org/10.1108/01437730010318174

Pate, J. (2006). The changing contours of the psychological contract: Unpacking context and circumstances of $\begin{array}{lllll}\text { breach. Journal of European Industrial Training, 30(1), } & \text { 32-47. }\end{array}$ http://dx.doi.org/10.1108/03090590610643860

Perrewe', P. L., Treadway, D. C., \& Hall, A. T. (2003). The work/family interface: Conflict, family-friendly policies, and employee well-being, in health and safety. In D. A. Hoffman, \& L. E. Tetrick (Eds.), Health and safety in organizations: A multilevel perspective (pp. 285-315). San Francisco, CA: Jossey-Bass.

Rousseau, D. M. (1995). Psychological contracts in organizations: Understanding written and unwritten agreements. Thousand Oaks, CA, US: Sage Publications, Inc.

Saltzstein, A. L., Ting, Y., \& Saltzstein, G. H. (2001). Work-family balance and job satisfaction: The impact of 
family-friendly policies on attitudes of federal government employees. Public Administration Review, 61(4), 452-467. http://dx.doi.org/10.1111/0033-3352.00049

Sels, L., Janssens, M., \& Van Den Brande, I. (2004). Assessing the nature of psychological contracts: A validation of six dimensions. Journal of Organizational Behavior, 25(4), 461-488. http://dx.doi.org/10.1002/job.250

Sturges, J., Conway, N., Guest, D., \& Liefooghe, A. (2005). Managing the career deal: The psychological contract as a framework for understanding career management, organizational commitment and work behavior. Journal of Organizational Behavior, 26, 821-838. http://dx.doi.org/10.1002/job.341

Templer, K. J. (2012). Five-Factor Model of Personality and Job Satisfaction: The Importance of Agreeableness in a Tight and Collectivistic Asian Society. Applied Psychology: An International Review, 61(1), 114-129. http://dx.doi.org/10.1111/j.1464-0597.2011.00459.x

Toegel, G., Anand, N., \& Kilduff, M. (2007). Emotion helpers: The role of high positive affcetivity and high $\begin{array}{lllll}\text { self-monitoring } & \text { Psychology, } & \text { 337-365. }\end{array}$ http://dx.doi.org/10.1111/j.1744-6570.2007.00076.x

Turnley, W. H., \& Feldman, D. C. (1999). A Discrepancy Model of Psychological Contract Violations. Human Resource Management Review, 9(3), 367-386. http://dx.doi.org/10.1016/S1053-4822(99)00025-X

Varawalla, S. A. (2009). Why is Job Satisfaction Important? Retrieved March 11, 2010, from http://ezinearticles.com/?Why-is-Job-Satisfaction-Important?\&id=3193636

Watson, D. (2000). Mood and temperament. New York, NY: Guilford Press.

\section{Copyrights}

Copyright for this article is retained by the author(s), with first publication rights granted to the journal.

This is an open-access article distributed under the terms and conditions of the Creative Commons Attribution license (http://creativecommons.org/licenses/by/3.0/). 